\title{
EXAMINATION OF SAMPLE COURSE DESIGN STUDIES PERFORMED BY PRE-SERVICE SOCIAL STUDIES TEACHERS BY USING DIGITAL TECHNOLOGIES
}

\author{
Dr. Turkan CELIK \\ ORCID: 0000-0001-8380-9419 \\ Faculty of Education \\ Kilis 7 Aralik University \\ Kilis, TURKEY
}

Received: 30/12/2019 Accepted: 30/06/2020

\begin{abstract}
The aim of this study is to examine the sample course design studies performed by pre-service social studies teachers by using digital technologies and to describe the opinions of pre-service teachers about this process. Design-based Research Model was used in the study. The study was conducted with 30 pre-service social studies teachers with criterion sampling technique. Data collection tools consisted of design documents, video recordings and interview forms. Descriptive analysis method was used for data analysis. Technological Pedagogical and Content Knowledge model was applied in the instructional process of the research. At the end of the 8-week instructional process, designs of pre-service teachers and their opinions about the process were obtained. In the research findings, course designs where pre-service teachers integrated their content knowledge and pedagogical knowledge with digital technologies, were acquired. Addition, all of the views of pre-service teachers on the process were found to be positive. In the context of these findings, it is concluded that technological pedagogical and content knowledge studies can be given with pre-service trainings. In this context, it is recommended to focus on pre-service training activities in future studies to be conducted and for any new researches, it is suggested to make longitudinal studies in order to monitor the effectiveness of this design model in real classroom environments.
\end{abstract}

Keywords: Design-based research, technology integration, social studies, pre-service teachers, digital education.

\section{INTRODUCTION}

The competency of teachers is important in the permanence of teaching and in designing an enriched learning environment. Because in addition to a teacher's content knowledge, the competencies explained by Shulman (1986) within the framework of pedagogical content knowledge are also important. According to the theory, teachers should have a deep content knowledge as well as pedagogical knowledge so that they can effectively teach their students. Because the ability to integrate the new technologies with content knowledge within the framework of pedagogical knowledge has become one of the most sought-after characteristics of teachers in this century. Because the 21st century teacher is expected to blend the content, pedagogical and technological knowledge correctly and share it with the students in the education process. "Pedagogical content knowledge", one of the three types of knowledge to be used in the integration process, is emphasized by the British pedagogue Shulman (1986). In the process of sharing knowledge with students, metaphors, reenactments, examples, explanations, concept explanations, presentations, and teaching methods used to formulate information and optimize it for the target audience to understand and pedagogical content knowledge with its techniques are effective in determining the expertise of teachers in their profession (Usak, 2005; Park \& Oliver, 2008). In one aspect, the quality of teaching activities is closely related to teachers' level of teaching competencies within the context of pedagogical content knowledge (Moore, 2000). Another factor that determines the quality of learning environments is teachers' mastery of "content knowledge". It is important how much the teachers can achieve the specific objectives of the course they are responsible for. This situation increases the importance of the teacher's content knowledge. It is important that pre-service social studies teachers, who are the focus of this study, have at least undergraduate level expertise about the social science disciplines that constitute the subjects under the umbrella of the learning fields such as "Individual and Society," "Culture and Heritage," "People, 
Places and Environments, "Science, Technology and Society, "Production, Distribution and Consumption," "Effective Citizenship" and "Global Connections" in the social studies curriculum (MoNE, 2018). Within the framework of their pedagogical skills, during an efficient education process, social studies teachers must teach about the important advantages of the 21st century such as "life and career skills," "learning and innovation skills" and "knowledge, media and technology skills". Among these skills, in the context of digital literacy, which is under the category of "information, media and technology skills," there are the fields of information, media, information and communication technologies. Information literacy skills make it possible to gain effective and accurate access to information, to evaluate the information accessed and to use this information correctly. Media literacy is closely related to individuals' ability to correctly analyze Web 2.0 and social media tools and to use them effectively in learning processes. On the other hand, "information and communication technologies literacy skills" express the ability to integrate technological tools such as computers, tablets, mobile phones into learning processes (Goksun \& Kurt, 2018). In this context, a person who is digitally literate is expected to have the knowledge and skills related to ethical and legal processes in the process of using information in a creative way, selecting useful information from different sources, accessing and using information in the solution of problems (Partnership for 21st Century Learning, 2015; Trilling \& Fadel, 2009). Therefore, digital technologies have an important function in this process, and teachers can use these tools in light of their "technological knowledge". Projectors and smart boards in classrooms and the internet available to be used in the educational context provide teachers with a digital door as they conduct the teaching process. Therefore, universities should improve their technological infrastructures in terms of mechanical and qualified academic staff and higher education institutions that train teachers should provide education to students in this direction (Kurt, 2013). Because technology has the role of creating more tools for the use of teachers and students, while the role of those responsible for teacher training is to train teachers who use technological tools correctly and appropriately (Koehler \& Mishra, 2005). Because the fact that educational environments are enriched with the use of technology cannot be denied (Melia, et al., 2012; Mishra \& Koehler, 2006). It is commonly known that technological tools have been around educational environments for a long time. Whereas, in the past, tools such as chalkboards, chalk, books, magazines, etc. existed in educational environments, with recent developments, internet and Web 2.0 technologies have been added to projectors, PowerPoint presentations, smart boards of today's classrooms. As a result of these developments, teachers can use applications such as Facebook, Blog, Wiki (Chou, 2011) as well as some digital applications built on Web 2.0 technologies. Some digital applications that today's teachers can easily adapt to many lessons (Benzer, 2017; Gununc, 2017; Esgi \& Kocadag Unver, 2018; Kazanci \& Donmez, 2013; Goksun \& Kurt, 2018; Onal, 2018; Sahin, 2013; Tatli, 2017) are presented in categories in Table 1 with the help of related literature.

Table 1. Digital applications that can be integrated with the courses in teacher education and MoNE

\begin{tabular}{|c|c|}
\hline CATEGORIES & WEB 2. 0 APPLICATIONS \\
\hline Mind Map Applications & $\begin{array}{l}\text { Wisemapping, Pooppet, SpiderScribe, Mindmeister, MindMaple } \\
\text { Lite, Inspiration 9, Gocongr,Coggle,Mindomo }\end{array}$ \\
\hline Dashboard Applications & Padlet, Blendspase, Lino it, Wordle, Bubble, RealtimeBord \\
\hline Poster and Cartoon Creation Applications & $\begin{array}{l}\text { Word Art, Canva, Make Beliefs Comix, Toondoo, Sketch toy, Face } \\
\text { Your Manga }\end{array}$ \\
\hline Story and Book Writing Applications & Pixton, Storyjumper, Storybord That, Storybird, Wattpad, Joomag. \\
\hline Note Taking and Blogging Applications & Evernote, Trello, Blogger, Tlumblr, Glogster \\
\hline Test and Puzzle Building Applications & $\begin{array}{l}\text { Flippquiz, Puzzlemaker, Kahoot, Plickers, Quiziz, Socrative, } \\
\text { mentimeter, LearningApss CrossWordLabs, Triventy. }\end{array}$ \\
\hline Presentation and Animation Applications & Prezi, Powtoon, Buncee, Emaze, Vyond,Voki, Mine-Imator, Scracth. \\
\hline $\begin{array}{l}\text { Information Poster and Infographic Preparation } \\
\text { Applications }\end{array}$ & Easelly, Visme, Piktochart, Venngage, Creately \\
\hline $\begin{array}{l}\text { Distance Education and Virtual Classroom } \\
\text { Applications }\end{array}$ & $\begin{array}{l}\text { Edmodo, Moodle, Classdojo, Remind, Beyaz Pano, Google } \\
\text { Clasroom, Adobe Connect, Bigblubutton,EBA. }\end{array}$ \\
\hline Virtual and Augmented Reality Applications & $\begin{array}{l}\text { Aurasma, Quiver, Morfo, Augmented Reality (AR), Nearpod, Uzay } 4 \\
\text { D, Animal 4D }\end{array}$ \\
\hline $\begin{array}{l}\text { Photography, Film and Video Editing and Design } \\
\text { Applications }\end{array}$ & $\begin{array}{l}\text { Thinglink, GIMPS, Mowi maker, Photostory, Safeshare, OpenShot, } \\
\text { Filmora, Nimbb, Jing, SmartDraw, Vocaro, Davinci } 15 \text { Beta, } \\
\text { Applnventor }\end{array}$ \\
\hline Social Media Applications & $\begin{array}{l}\text { Blog, Wiki, Youtube, Skype, Houngout, Whatsapp, Facebook, } \\
\text { Instagram, WebQuest. }\end{array}$ \\
\hline
\end{tabular}


In new learning perspectives, educational environments have now shifted from a teacher-centered approach to a student-centered one. Web 2.0 applications, which are important tools of information and communication technologies in new instructional environments designed in line with constructivist approach, support the active and participatory role of the student in learning processes as well as the constructivist approach. Therefore, the use of Web 2.0 tools in educational processes is consistent with educators such as Vygotsky, Jean Piaget and Jerome Bruner, as well as educational theories such as problem-based learning, correlative learning, distributed cognition, cognitive flexibility theory, cognitive apprenticeship, situated learning, selfregulated learning (Gunduz, 2007).

\section{Social Studies Curriculum and Digital Technologies}

One of the most remarkable of the subjects that make up the eight titles of the Turkish Qualifications Framework (TQF) in the curricula is "digital competence". The competencies in the digital field, which should be emphasized in particular, are related to media, internet and social networks which have become integral parts of the individual in social life. Through the training given in the context of the program, it is observed that the basic skills such as access to information, the use of computers for the evaluation, storage, production, presentation and exchange of information, participation in common networks via the internet and communication are expected to be integrated with digital competence skills. This is supported by the specific objectives of the social studies curricula (MoNE, 2018). 27 skills that are aimed to be taught within the scope of Social Studies Course "perception of change and continuity," "digital literacy" and "media literacy" again emphasize the importance of this issue. The description of one of the learning areas that constitute the backbone of the program, "science, technology and society," emphasizes the importance of helping students gain an innovative and critical thinking perspective in social studies courses for the development of science and technology. In addition, students are expected to gain the ability to use technology consciously by seeing examples of the effects of science and technology on social life in this learning area. Therefore, it is important that teachers enrich their courses with activities that will feed digital competence in social studies teaching process. Additionally, organizing technology-assisted learning environments in indicates that the 21 st century teacher has become technologically competent and productive (Goksun \& Kurt, 2018). However, the literature shows that there are some problems that prevent the use of technology in the education process. It is indicated that there are external factors such as equipment, time and technical support, as well as internal factors such as belief, attitude, self-confidence, which prevent technology from inducing change in educational environments by being integrated into traditional learning as a single discipline (Ertmer, 2005, Mazman \& Kocak-Usluel, 2011). This requires a profound reform of the initial teacher training process, and according to the United States Office of Technology Assessment (1995), the most immediate and effective solution to this problem is through pre-service teacher training (Hur et al., 2010). However, the quality of education provided in faculties of education may not always be the same. Because studies (Russell et al., 2003; Doering et al., 2003; Hew \& Brush, 2007; Karuki \& Duran, 2004; Pope et al., 2002) show that due to technology being taught as a single discipline rather than being integrated to courses, the Technological Pedagogical Content Knowledge (TPACK) skills of pre-service teachers do not fully develop. Moreover, in the study findings of Karuki and Duran (2004), it was stated that many faculties of education in the U.S. mostly focused on developing technological knowledge of pre-service teachers rather than integrating technology use into courses. Similarly, another study conducted abroad, (Russell et al., 2003) showed that a large number of new teachers used technology only in preparing syllabi instead of integrating technology into their fields and felt uncomfortable using classroom technology. Therefore, it is seen that pre-service teachers have difficulty in using technological knowledge in the teaching process due to the fact that technology is taught to them as a separate discipline without being integrated with field knowledge and pedagogical knowledge during pre-service teacher training (Doering et al., 2003; Hew \& Brush, 2007; Pope et al., 2002). In some studies, pre-service teachers were observed to have problems not only in terms of integrating technology into their fields but also in using it. It is noted that these problems have various sources. For example, in some studies, it was concluded that pre-service teachers did not feel competent enough to use technology (Pamuk et al., 2012), and in others (Graham et al., 2009; Meric, 2014) it was concluded that pre-service teachers it was due to a lack of self-confidence and also related to their self-efficacy perceptions (Abbitt \& Klett, 2007; Gomleksiz \& Fidan, 2011). There are also studies 
emphasizing that increasing the self-confidence of pre-service teachers in this context, depends on their getting technologically supported trainings (Brown \& Warschauer, 2006; Lee et al., 2008). In addition to the studies conducted with pre-service teachers, in another study (Collis \& Moonen 2008) where people working as teachers were the subject, it was stated that teachers were reluctant to use technology because they did not have sufficient equipment to integrate technology with their fields. Therefore, no movements of innovation in the field of education will be successful unless they are well understood and internalized by teachers (Baki, 2002). Therefore, in order to solve the problem in question, it becomes clear that it is necessary to teach how technology should be integrated with the courses in education faculties first.

\section{Significance of the Research}

Digital learning materials have an important role not only to enrich educational environments but also enable students from all around the world to reach the information from their home. Especially, along with the spread of recent COVID-19 pandemic across the world, the importance of distance education is heavily recognized. Because of the pandemic, many countries had to switch distance education which requires the use of digital learning materials and skills to use these materials. However, as seen in the literature of this research, it was found that teachers and pre-service teachers had problems in the process of integrating technology and their pedagogical knowledge. Researches have shown that the reason for these problems arise from the fact that technology is taught to pre-service teachers as a separate discipline. In this context, the healthy integration of digital technologies in the teaching process depends on informing and empowering today's teachers. However, this cannot be a solution on its own. One of the parts of a permanent solution requires delving into the source of the problem, meaning the process of teacher training. In this respect, it is necessary to increase the quality of teaching in terms of the practical use of digital technologies in the faculties of education. In this regard, the "Digital Transformation in Higher Education" project created by Anadolu University and Council of Higher Education of Turkey (YOK) is currently being implemented in certain universities and these ongoing projects need to be supported by other universities as well. In this respect, it is important that pre-service teachers become more competent by having their related courses integrated with digital technologies during their education processes. The significance of integrating technology to the educational environment is also reflected by Ministry of National Education's (MEB) Vision 2023 plan and 21st century learning skills (Bozkurt, 2019).

Therefore, this study, which aims to design and implement a course integrated with digital technologies with pre-service teachers, will contribute both to the 21 st century's educational needs and the field.

\section{Purpose}

The purpose of this study is to examine the sample course design studies conducted by pre-service social studies teachers using digital technologies and to describe their opinions about this process. The research questions created in this context are as follows:

1. How did pre-service social studies teachers design a course in the process of designing a sample course with digital technologies?

2. What is the distribution of the content prepared by pre-service teachers in the process of designing a sample course with digital technologies in terms of grade, learning area, digital application and activities/techniques used?

3. Which digital applications have pre-service social studies teachers used in the process of designing a sample course with digital technologies?

4. What are the opinions of pre-service social studies teachers about the process of designing a sample course with digital technologies? 


\section{METHOD}

\section{Research Model}

Design-based Research Model was used in this study. Design-based research is a method that emerged from the need of formative research regarding theoretical education designs (Cobb et al., 2003; Collins et al., 2004) and the need to take the interaction of design, theory, and application trio to the next level. Design-based research was first put forward by Brown (1992) and Collins (1992) with the name of design experiments. Design experiments are known as a research method which includes scientific processes such as discovery, disclosure, verification and dissemination and active participation of the researcher in instructionlearning activities (Kelly, 2003). In design-based research, the researcher conducts the research with the participants and is an important part of the research process (Cobb et al., 2003). The researcher systematically designs and implements interventions, reviews and develops the initial design according to the results of the application and reapplies it. The researcher continues this process cyclically until he/she thinks that the application made from a pragmatist perspective is sufficiently developed. In this respect, it is possible to design and develop products in three different types with the design-based research method (Design-Based Research Collective, 2003). These types are; developing innovative learning environments, developing new classroom practices and developing new learning theories. In addition, it is possible to develop an innovation, product or theory at the end of the design-based research process. Levin and O'Donnell (1999) state that the fact that most of the research methods commonly used in educational research fall short of producing convincing experimental evidence causes loss of trust in educational research. In this context, design-based research method is seen as a positive effort in eliminating this loss of trust in educational research (Levin \& O'Donnell, 1999). However, the application steps of design-based research are not as clear as quantitative research. Depending on the context, the research processes can vary greatly. However, the general path to follow is; first, the designer develops and implements the initial version of his/her design. Then, he/she looks at how the design works in practice. As a result of the experience gained from the implementation, the designer regularly reviews the design and makes corrections. The design becomes solid, error-free and productive over time. Finally, the research report is written. A design-based research is made up of holistic systems and change in one part can affect the whole and other parts of the whole (Brown \& Campione, 1996). Therefore, the evaluation of designs is a continuous process and as the design changes, the evaluation process changes along with it. Design-based research, which requires a dynamic process to achieve a positive goal, is similar to action research in this respect. However, while the aim of action research is to solve a problem, in design-based research, this aim turns into designing and implementing a product.

\section{Study Group}

Participants of the study were selected by using criterion sampling technique from among the purposive sampling methods. 30 pre-service social studies teachers, who were taking the "Special Teaching Methods I" course in the spring term of the 2018-2019 academic year, were selected for the study based on purposive sampling methods. Criteria for selection of participants were; to be in a group where a course is designed with digital technologies in the context of pedagogical and content knowledge, to have taken courses such as Teaching Principles and Methods, Computer or Information Technologies, Instructional Technology and Material Design in addition to courses such as History, Geography, Philosophy, Sociology. In addition, volunteering of all participating pre-service teachers constitutes another criterion of the study.

\section{Design Process}

The objective of this study is to design and implement a social studies course integrated with digital technologies. In line with this objective, the researcher provided 4 weeks of theoretical training to the participants. The researcher has an important role in the process of giving trainings. Being an expert in the field of media/social media literacy and having work experience and publications related to the use of digital technologies and Web 2.0 tools in educational processes, helped the researcher identify and manage the tools to be used in the educational process. An 8-week implementation time was set for the presentation of the design studies. The groups of at least 2 and 4 people, which the researcher formed during the theoretical 
training, started to work on a sample social studies course project that they would integrate with digital technologies towards the end of the theoretical training. The drafts were implemented in a classroom environment and evaluated in terms of their usefulness. Angeli and Valanides (2009) emphasize the fact that teaching models and applications aiming at gaining the necessary knowledge and skills for technology assisted instruction include real learning environments and in-class applications. However, due to the fact that the participants of this study were 3rd Grade university students, they did not have the opportunity to use the courses they designed in a real classroom environment. Alternatively, they created in their own classrooms an environment similar to a real classroom and applied their courses there. The researcher gave the groups feedback for the resulting course designs each week and motivated them. Since the designs would be evaluated in their entirety, different variables in addition to the products of the groups were considered in the evaluation of group success. Collins et al. (2004) assert that there are points of consideration for evaluating a design, which are cognitive, interpersonal, group/grade, resource, institution or school levels. In the method used in this study, the aforementioned levels were considered as follows:

\section{Cognitive Level}

At this level, the course design activities, the processes of teaching the designed course and reflective thoughts about the process of pre-service social studies teachers were determined. At the same time, the groups were videotaped while presenting and then the students tried to reflect on their work by watching the videos.

\section{Interpersonal Level}

Pre-service social studies teachers carried out a course design study using digital materials as part of a group. A total of 8 groups carried out studies. Each group shared their work step by step with the instructor and received correctional feedback. During the process, pre-service teachers were encouraged to collaborate both within and between groups. Jigsaw technique was used in the process. As a matter of fact, in the majority of technology based instructional design models, collaborative learning approach is applied in which preservice teachers work in groups (Lu et all., 2011; So \& Kim, 2009). The feedback-corrections given to the groups who made their presentations in the classroom environment were instructive in terms of other groups not repeating the same mistakes.

\section{Group or Grade Level}

Pre-service social studies teachers tried to create an environment similar to a real middle school classroom in their courses designed with digital materials. In this process, other pre-service teachers in the classroom supported the groups that presented their studies by playing the role of secondary school students. Each group made sacrifices for its success and there were certain roles assigned within the groups. In addition, the groups who were more successful in designing their products collaborated with the members of other groups and then returned to their own groups.

\section{Resource Level}

In this process, digital applications (Kahoot, Triventy, Canva, Powton, etc.) where teacher candidates would prepare digital materials were introduced and the steps to use them were shared with the pre-service teachers. The pre-service teachers were notified that these resources could be used for free or by paying, with or without a set period of use. They were then asked to design their courses while keeping that information in mind.

\section{Institution or School Level}

In the faculties of education where the implementations took place, the managers of the institutions supported the process. Especially, the maintenance, repair and internet connection problems of smart boards were tried to be solved. In addition, the instructor was given the responsibility of "Instructional Technologies and Material Design Exhibition" at the end of the year due to the use of an innovative educational model in 
the faculty, thus providing both motivation and moral support. In short, the characteristics of the teaching model applied in this research can be summarized in four main steps. These steps, which form a cyclic whole, are presented in Figure 1.

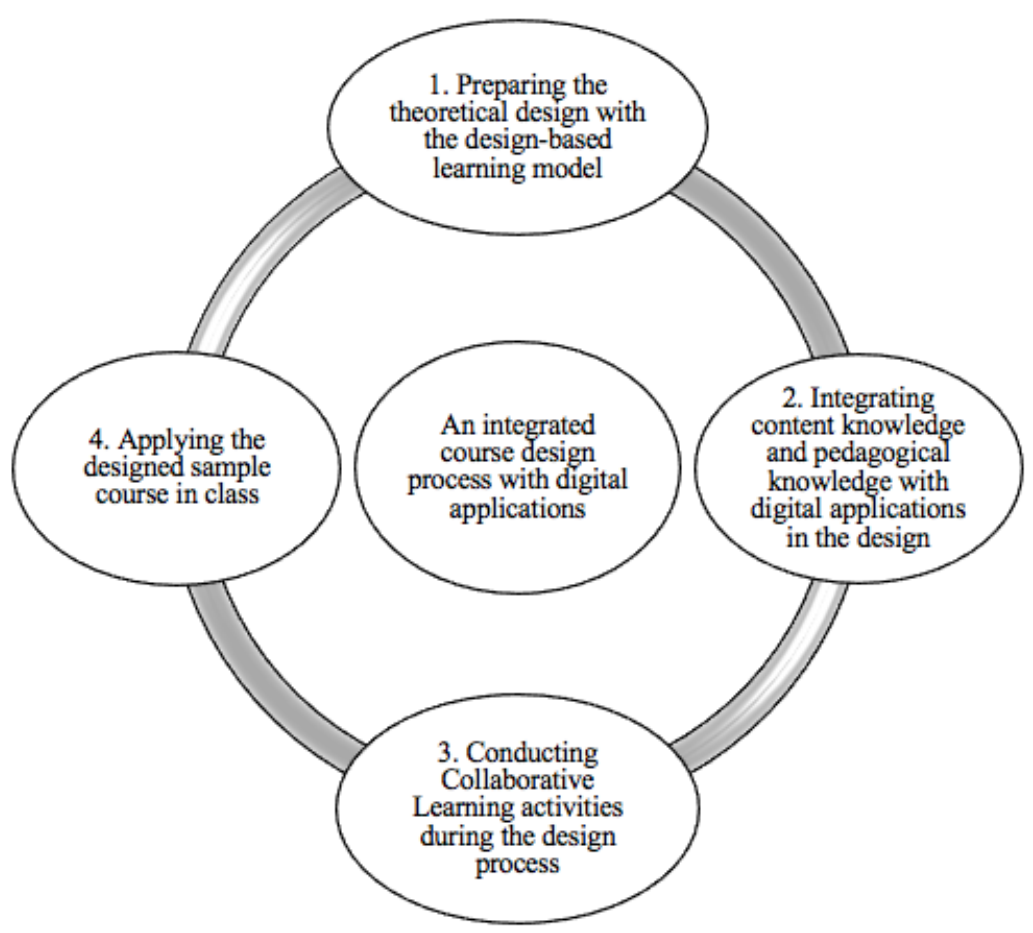

Figure 1. A representative module of the steps performed within the scope of the teaching model used in the research

\section{Data Collection Process}

The data collection process of the research was carried out according to the design-based learning method. The researcher shared information with the pre-service teachers during the 4-week period of a semester. In this period, teaching methods and techniques that pre-service teachers would use in social studies education were discussed. Additionally, it was stated that pre-service teachers would design a social studies course with digital technologies within the framework of pedagogical and content knowledge. In this process, the preservice teachers were allowed to choose the level of social studies course, learning area, teaching technique and digital applications to be used. In addition, the form containing the digital applications discussed in the theoretical part of the course (presented in Table 1) was given to them by the researcher, and they were given the opportunity to choose the application appropriate for their designs. The researcher gave a few examples of how to use the digital applications from the form for social studies courses, used them on a smart board step by step and helped the pre-service teachers to use them. The part of the study based on group practices lasted 8 weeks. Each group presented their lessons in a classroom environment and were videotaped and watched themselves again. Also, while the groups introduced their applications, other pre-service teachers in the class acquired more information regarding different digital applications each week. In order to enable each group member to work actively in the process, 4 course designs were requested from each group. The processes to be carried out by the groups in the design process consisted of 4 stages and they were:

- Preparing the theoretical design with Design-based Learning model: Pre-service teachers are asked to review the learning areas, subjects and digital applications that they already knew about and which were included in the social studies curriculum.

- Integrating content knowledge and pedagogical knowledge into digital applications in design: By synthesizing their knowledge and skills in social studies learning areas, teaching techniques and digital applications. They form the infrastructure of the sample course. 
- Conducting Collaborative Learning activities in the design process: In this step, pre-service social studies teachers work in group and inter-group collaboration with their friends. Each group member plays an active role in the process to partake in the learning and teaching of the design process.

- Application of the designed sample course in the classroom: Pre-service teachers conduct the social studies course designed with digital technologies in an environment similar to a real secondary school classroom. Their classmates take on the role of middle school students and they act as teachers themselves. Then, they redevelop their designs according to the feedback-corrections from the researcher. In addition, the activities in this step are videotaped.

\section{Data Collection Tools}

\section{Documents for Developing a Social Studies Course with Digital Applications}

A form for designing a Social Studies Course with digital materials was prepared by the researcher beforehand. In this form, the parts regarding classroom level, learning area, teaching techniques to be used and digital materials to be used were left blank for the pre-service teachers to fill in. The pre-service teachers filled in the relevant parts of this form and submitted it to the researcher before creating their designs. Two experts were consulted for the suitability of the form.

\section{Participant (Pre-service Teacher) Opinions}

One of the data collection tools of this study is the interview technique. Interview technique can be used as the main data source of the research as well as with other data collection techniques such as participant observation and document collection. Such use of interviews also enables the verification of the data obtained through observation and document analysis and the creation of alternative explanations for the data (Buyukozturk et al., 2008; Glesne, 2013). In this study, data were collected from pre-service teachers through a semi-structured interview form to describe their opinions on the process. Collecting data from the participants through interview method allows the control of the data obtained through observation and document analysis from the participants' perspectives and can contribute positively to the reliability and validity of the research (Merriam, 2013).

\section{Observation (Video Recordings)}

Observation is considered to be one of the most important ways to obtain this data (Merriam, 2013). Keeping field notes to obtain useful data from observations made during the research process (Mayring, 2011), is also common practice in addition to recording audio and video in the environment where the observation takes place (Merriam, 2013; Yildirim \& Simsek, 2013). During this research, sample social studies courses designed by a different group each week were recorded with a video recorder including audio recording. It is known that video recording of the observations contributes to the credibility of the research as well.

\section{Analysis of the Data}

The documents, interview data and video recordings collected during this research were examined by descriptive analysis method. Descriptive analysis is the interpretation and summarization of previously collected data under certain themes or titles (Altunisik et al., 2007; Yildirim \& Simsek, 2013). In this study, the researcher firstly formed a framework by bringing together the written, visual and audio products collected from each pre-service teacher under a code (P1, P2...) assigned to each respective teacher. Then, these data were examined, and themes were created. In addition to the excerpts from the documents of the pre-service teachers related to each theme, statistical values of how many pre-service teachers used each theme are presented. In brief, there are four steps of descriptive analysis; creating the framework, processing data according to the thematic framework, identifying and interpreting the findings. In this study, the findings presented with different themes by each group were supported with video recordings in order to increase the credibility of the research. 


\section{Reliability and Validity}

For the validity and reliability studies of this research, the preparation of data collection tools, data collection process, data analysis and recording processes were carried out very carefully. In the process of preparing the data collection tools, in addition to two field experts, a Turkish teacher was also consulted in order to determine the language suitability of the data collection tools. Participants were selected on a voluntary basis. The participants were also informed that they could leave the study process (participation in the research, data collection, video recording, broadcasting on YouTube) at any time. In order to increase the credibility of the research, the application of the designed courses was recorded on video and these data were also shared on social media (Turkan Hoca Dijital Materyal Egitimi, 2019). No financial gain was sought from this social media channel and only the work done for the integration of digital technologies was shared with other stakeholders and colleagues throughout the education process. Signed permission was obtained from the pre-service teachers to share their videos and they were informed that their videos could be removed if they wanted at any time. Necessary information regarding the work and the procedures was given to the authorities of the institutions and permissions were obtained.

\section{FINDINGS}

\section{How did Pre-service Social Studies Teachers Design Sample Social Studies Courses with Digital Technologies?}

Table 1. How are the samples designs made by pre-service social studies teachers with digital technologies?

\begin{tabular}{|c|c|c|c|}
\hline $\mathbf{P}$ & DIGITAL APPLICATIONS (TK) & $\begin{array}{c}\text { ACTIVITIES AND TECHNIQUES } \\
\text { USED (PK) }\end{array}$ & $\begin{array}{c}\text { SOCIAL STUDIES LEARNING } \\
\text { AREA (CK) }\end{array}$ \\
\hline \multicolumn{4}{|c|}{ 1st. Group } \\
\hline P1 (URL-2) & $\begin{array}{l}\text { Buncee, Thinglink, Popplet, } \\
\text { Goconr }\end{array}$ & $\begin{array}{l}\text { More Tomorrow, Get the Flag } \\
\text { Answer the Question }\end{array}$ & $\begin{array}{l}\text { 5th Grade People, Places and } \\
\text { Environments }\end{array}$ \\
\hline P2 & $\begin{array}{l}\text { Neaorpod, Popplet, Quiziz } \\
\text { Wondershare filmora }\end{array}$ & $\begin{array}{l}\text { Market Place Technique, Draw and } \\
\text { Find Technique, Assemble Parts }\end{array}$ & 5th Grade Global Connections \\
\hline P3 & $\begin{array}{l}\text { Goconqr, Powtoon, Storyjumper, } \\
\text { Triventy }\end{array}$ & Quick Round, Knock Over and Win & 5th Grade Culture and Heritage \\
\hline P4 & Neorpad Aurasma Learning apps & Station, Build and Solve & $\begin{array}{l}\text { 5th Grade Production, } \\
\text { Distribution and Consumption }\end{array}$ \\
\hline \multicolumn{4}{|c|}{ 2nd. Group } \\
\hline P5 (URL-3) & $\begin{array}{l}\text { Emaze Go animate, } \\
\text { Learningsapps }\end{array}$ & Question Round, Take a Hint & $\begin{array}{l}\text { 5th Grade People, Places and } \\
\text { Environments }\end{array}$ \\
\hline P6 & Goanimate Thinglink, Mentimeter & Remember and Win, Quick Round & $\begin{array}{l}\text { 5th Grade Science, Technology } \\
\text { and Society }\end{array}$ \\
\hline P7 & $\begin{array}{l}\text { Movie maker, Easelly } \\
\text { Crooswordlabs }\end{array}$ & Collect Points, Aquarium & 6th Grade Culture and Heritage \\
\hline P8 (URL-4) & Thinglink Aurasma Socrative & True or False? What Does It Have? & $\begin{array}{l}\text { 6th Grade People, Places and } \\
\text { Environments }\end{array}$ \\
\hline \multicolumn{4}{|c|}{ 3rd. Group } \\
\hline P9 (URL-5) & Mindomo, Triventy & $\begin{array}{l}\text { Everybody Is a Teacher Here, Cast } \\
\text { a Line Get the Question }\end{array}$ & $\begin{array}{l}\text { 5th Grade People, Places and } \\
\text { Environments }\end{array}$ \\
\hline P10 (URL-6) & $\begin{array}{l}\text { Padlet,Storyjumper,Aurasma, } \\
\text { Goanimate, Safeshare, } \\
\text { Learningapps }\end{array}$ & $\begin{array}{l}\text { Come Out Come Out Wherever } \\
\text { You Are, Hit the Dart Answer the } \\
\text { Question }\end{array}$ & 6th Grade Culture and Heritage \\
\hline P11 (URL-7) & Thinglink, Flipguiz, Prezi & Court, Gossip & 5th Grade Active Citizenship \\
\hline P12 & Canva, Word Art, Kahoot & Card Matching, Be Quick and Win & $\begin{array}{l}\text { 5th Grade Science, Technology } \\
\text { and Society }\end{array}$ \\
\hline
\end{tabular}




\begin{tabular}{|c|c|c|c|}
\hline \multicolumn{4}{|c|}{ 4th. Group } \\
\hline P13 & $\begin{array}{l}\text { Canva, Thinglink, Go animate, } \\
\text { Mentimeter }\end{array}$ & $\begin{array}{l}\text { Idea Scan, Wheel of Fortune, Get } \\
\text { Your Bearings }\end{array}$ & 5th Grade Global Connections \\
\hline P14 & $\begin{array}{l}\text { Classdojo, Powtoon, Storyjumper, } \\
\text { Learningapps, Lino-it, Quizizz }\end{array}$ & Role Playing, Playing Tag & 7th Grade Culture and Heritage \\
\hline P15 & Powtoon, Storyjumper Flipguiz & Information Pouch, Listing & 5th Grade Active Citizenship \\
\hline P16 & Lino it, Plickers & Station, Basket of Apples & $\begin{array}{l}\text { 7th Grade Production, } \\
\text { Distribution and Consumption }\end{array}$ \\
\hline \multicolumn{4}{|c|}{ 5th. Group } \\
\hline P17 (URL-8) & $\begin{array}{l}\text { Emaze, Thinglink, Toondoo, } \\
\text { Mentimeter }\end{array}$ & $\begin{array}{l}\text { More Tomorrow, Guess and Find } \\
\text { Me }\end{array}$ & 5th Grade Global Connections \\
\hline P18 & Prezi, Mentimeter, Thinglink & $\begin{array}{l}\text { Analogy (Metaphor), Ring a Ring } \\
\text { o' Roses }\end{array}$ & $\begin{array}{l}\text { 5th Grade People, Places and } \\
\text { Environments }\end{array}$ \\
\hline P19 & $\begin{array}{l}\text { Wisemapping, Emaze, Learning } \\
\text { Apps, Padlet-Socrative }\end{array}$ & True or False, Alternating Learning & $\begin{array}{l}\text { 7th Grade Science, Technology } \\
\text { and Society }\end{array}$ \\
\hline P20 & Kahoot, Wordle & Flashcards, Listing & 5th Grade Active Citizenship \\
\hline \multicolumn{4}{|c|}{ 6th. Group } \\
\hline P21 & $\begin{array}{l}\text { Amaze, Quzizz, Wisemapping, } \\
\text { Crossword Laps }\end{array}$ & $\begin{array}{l}\text { Flashcards, Come Out Come Out } \\
\text { Wherever You Are }\end{array}$ & 6th Grade Global Connections \\
\hline P22 & $\begin{array}{l}\text { Learning Apps, Goanimate, } \\
\text { Easelly }\end{array}$ & Quick Round, Hourglass & $\begin{array}{l}\text { 7th Grade Production, } \\
\text { Distribution and Consumption }\end{array}$ \\
\hline P23 & $\begin{array}{l}\text { Mindmeister, Canva, Blendspace, } \\
\text { Quizizz }\end{array}$ & Court, Race Against Time & 6th Grade Active Citizenship \\
\hline $\mathrm{P} 24$ & Quiziz, Emaze, Mindmeister & Hourglass, True or False? & 5th Grade Culture and Heritage \\
\hline \multicolumn{4}{|c|}{ 7th. Group } \\
\hline P25 & Blendspace, Powtoon, Quizizz & Roller, Role Playing & $\begin{array}{l}\text { 6th Grade People, Places and } \\
\text { Environments }\end{array}$ \\
\hline P26 & Emaze, Socrative, Bubbl & Speaking Circle, Who Does It? & 7th Grade Culture and Heritage \\
\hline P27 & Voki, Flipguiz, Thinglink & $\begin{array}{l}\text { Card Matching, Burst the Bubble } \\
\text { See the Answer }\end{array}$ & 5th Grade Culture and Heritage \\
\hline P28 & Voki, Canva, Kahoot & $\begin{array}{l}\text { Treasure Hunt, Questions and } \\
\text { Answers }\end{array}$ & $\begin{array}{l}\text { 5th Grade Individual and } \\
\text { Society }\end{array}$ \\
\hline \multicolumn{4}{|c|}{ 8th. Group } \\
\hline P29 & Emaze, Voki, Quizizz & Drama, The Stranger Next to Me & 6th Grade Active Citizenship \\
\hline P30 & Neopad, Mentimeter, Pooplet & Six Shoes, Argumentation & 7th Grade Global Connections \\
\hline
\end{tabular}

When Table 1 is examined, it is observed that each group designed and presented 4 sample social studies courses. It is seen that both individual products and common group products have emerged during the group work. It is evident in this finding that, particularly in collaborative studies, balanced work takes place within the groups, which is important for preventing unfairness within groups. Because there are four people in each group, it is noteworthy that the four courses designed together are each presented by a single group member. The fact that pre-service teachers apply teaching techniques in social studies courses where they use digital applications in the context of class level and learning areas in the social studies curriculum, also draws attention. In addition to the teaching techniques (e.g. come out come out wherever you are, quick round, hourglass) in the literature, it was observed that pre-service teachers also used instructional activities they created themselves (the stranger next to me, hit the dart answer the question, cast a line get the question). When the videos of pre-service teachers about the social studies course designed with digital technologies are examined, it is observed that the designs created are also suitable for constructivist understanding and student participation. 


\section{What Is the Distribution of the Content Prepared by Pre-service Teachers in the Process of Designing a Sample Course with Digital Technologies in Terms of Grade, Learning Area, Digital Application and Activities/Techniques Used?}

Table 2. Distribution of the designed courses in terms of grade level, learning area, digital applications and techniques used

\begin{tabular}{|c|c|c|c|c|}
\hline Grade & Learning Area & f & $\begin{array}{l}\text { Which Digital Applications Are Used in This } \\
\text { Field }\end{array}$ & $\begin{array}{l}\text { What Are the Learning Techniques } \\
\text { Used? }\end{array}$ \\
\hline $5,6,7$ & $\begin{array}{l}\text { Culture and } \\
\text { Heritage }\end{array}$ & 7 & $\begin{array}{l}\text { Storyjumper (3), Powtoon (2), Quizizz (2), } \\
\text { Emaze (2), Triventy (1), Movie Maker (1), Easelly } \\
\text { (1), Crooswordlabs (1) Goconqr (1), Padlet (1), } \\
\text { Aurasma (1), Goanimate (1), Safeshare (1), } \\
\text { Learningapps (2), Classdojo (1), Lino It (1), } \\
\text { Mindmeister (1), Socrative (1), Bubble (1), Voki } \\
\text { (1), Flipquiz (1), Thinglink (1) }\end{array}$ & $\begin{array}{l}\text { Quick Round (1), Knock Over and } \\
\text { Win (1), Collect Points (1), Aquarium } \\
\text { (1), Role Playing (1), Playing Tag } \\
\text { (1), Hourglass (1), True or False? (1), } \\
\text { Speaking Circle (1), Who Does It (1), } \\
\text { Card Matching (1), Burst the Bubble } \\
\text { See the Answer (1) }\end{array}$ \\
\hline 5,6 & $\begin{array}{l}\text { People, } \\
\text { Places and } \\
\text { Environments }\end{array}$ & 6 & $\begin{array}{l}\text { Thinglink (2) Buncee (1), Popplet (1), Goconr } \\
\text { (1), Emaze (1), Go Animate (1) Learningsapps (1), } \\
\text { Mindomo (1), Triventy (1), Prezi (1), Mentimeter } \\
\text { (1), Blendspace (1), Powtoon (1), Quizizz (1) }\end{array}$ & $\begin{array}{l}\text { More Tomorrow (1), Get the Flag } \\
\text { Answer the Question (1), Question } \\
\text { Round (1), Take a Hint (1), True or } \\
\text { False? (1) What Does It Have? (1) } \\
\text { Everybody Is a Teacher Here (1), Cast } \\
\text { a Line Get the Question (1), Analogy } \\
\text { (Metaphor) (1), Ring a Ring o' Roses } \\
\text { (1), Roller (1), Role Playing (1) }\end{array}$ \\
\hline $5,6,7$ & $\begin{array}{l}\text { Global } \\
\text { Connections }\end{array}$ & 5 & $\begin{array}{l}\text { Mentimeter (3), Neaorpod (2), Popplet (2), } \\
\text { Quizizz (2), Thinglink (2), Emaze (2), Wondershare } \\
\text { Filmora (1), Canva (1), Go Animate (1), Toondoo } \\
\text { (1), Wisemapping (1), Crossword Laps (1) }\end{array}$ & $\begin{array}{l}\text { Idea Scan (1), Wheel of Fortune } \\
\text { (1), Get Your Bearings (1), More } \\
\text { Tomorrow (1), Guess and Find Me } \\
\text { (1), Flashcards (1), Come Out Come } \\
\text { Out Wherever You Are (1) }\end{array}$ \\
\hline 5,6 & $\begin{array}{l}\text { Active } \\
\text { Citizenship }\end{array}$ & 5 & $\begin{array}{l}\text { Quizizz (3), Flipquiz (2), Prezi (1), Powtoon } \\
\text { (1), Storyjumper (1), Kahoot (1) Wordle (1), } \\
\text { Mindmeister (1), Canva (1), Blendspace (1), } \\
\text { Emaze (1), Voki (1) Thinglink (1) }\end{array}$ & $\begin{array}{l}\text { Court (2), Gossip (1), Information } \\
\text { Pouch (1), Listing (1), Flashcards (1), } \\
\text { Race Against Time (1), Drama (1), } \\
\text { The Stranger Next to Me (1) }\end{array}$ \\
\hline 5,7 & $\begin{array}{l}\text { Science, } \\
\text { Technology } \\
\text { and Society }\end{array}$ & 3 & $\begin{array}{l}\text { Goanimate (1), Thinglink (1), Mentimeter (1), } \\
\text { Canva (1), Word Art (1), Kahoot (1), Wisemapping } \\
\text { (1), Emaze (1), Learning Apps (1), Padlet (1), } \\
\text { Socrative (1) }\end{array}$ & $\begin{array}{l}\text { Remember and Win (1), Quick } \\
\text { Round (1), Card Matching (1), Be } \\
\text { Quick and Win (1), True or False (1), } \\
\text { Alternating Learning (1) }\end{array}$ \\
\hline 5,7 & $\begin{array}{l}\text { Production, } \\
\text { Distribution } \\
\text { and } \\
\text { Consumption }\end{array}$ & 3 & $\begin{array}{l}\text { Learning Apps (2), Neorpad (1), Aurasma (1), } \\
\text { Lino It (1), Plickers (1), Goanimate (1), Easelly (1) }\end{array}$ & $\begin{array}{l}\text { Station (2), Build and Solve (1) } \\
\text { Basket of Apples (1), Quick Round } \\
\text { (1), Hourglass (1) }\end{array}$ \\
\hline 5 & $\begin{array}{l}\text { Individual and } \\
\text { Society }\end{array}$ & 1 & Voki (1), Canva (1), Kahoot (1) & $\begin{array}{l}\text { Treasure Hunt (1), Questions and } \\
\text { Answers (1) }\end{array}$ \\
\hline
\end{tabular}

When Table 2 is examined, it is seen that the learning area the participants prepared the most content for during the process of integrating their technological pedagogical content knowledge in the social studies course was the "Culture and Heritage" (7) learning area. In this area of learning, content was prepared for 5th, 6th, and 7th Grade levels. Similarly, in the "global connections" learning area, technological, pedagogical and content knowledge studies have been carried out extensively for the 5th, 6th and 7th Grades. The most frequently preferred digital applications for course integration in terms of specific learning areas were as follows; a digital storytelling app called "Storyjumper" (3) for the Culture and Heritage learning area, Thinglink "(2), for the People, Places and Environments learning area, "Mentimeter" (3), for the Global Connections learning area, "Quiziz" (3), for the Active Citizenship learning area and finally, "Learning Apps "(2), for the Production Distribution and Consumption learning area. However, it was observed that for the Individual and Society and Science, Technology and Society learning areas, different applications were used only once. In the pre-service teachers' preferences of using instructional techniques, there were no repeated techniques other than "Court" (2) and "Station" (2) techniques. This finding shows that social studies teachers produce different contents within the scope of their creativity. In addition, pre-service teachers also created some activities such as "Knock Over and Win, Collect Points, Playing Tag, Burst the Bubble See the Answer, Take a Hint, Cast a Line Get the Question" themselves. 
Which Digital Applications Did Pre-service Social Studies Teachers Used in the Process of Designing A Sample Course with Digital Technologies?

Table 3. Digital applications mainly used in the process of designing a sample course with digital technologies

\begin{tabular}{llll}
\hline Digital applications used & $\mathbf{f}$ & Digital applications used & $\mathbf{f}$ \\
\hline Thinglink & 8 & Blendspace & 2 \\
Quiziz & 7 & Easelly & 2 \\
Emaze & 7 & Crooswordlabs & 2 \\
Learning Apps & 6 & Prezzi & 2 \\
Go animate (Vyond) & 5 & Wisemapping & 2 \\
Mentimeter & 5 & Lino-it, & 2 \\
Powtoon, & 4 & Triventy & 2 \\
Storyjumper & 4 & Padlet & 2 \\
Canva & 4 & Movie maker & 1 \\
Popplet, & 3 & Mindomo & 1 \\
Neaorpod & 3 & Buncee & 1 \\
Aurasma & 3 & Safeshare & 1 \\
Socrative & 3 & Word art & 1 \\
Voki & 3 & Classdojo & 1 \\
Kahoot & 3 & Plickers & 1 \\
Flipguiz & 3 & Toondoo & 1 \\
Goconqr & 2 & Wordle & 1 \\
Mindmeister & 2 & Bubbl & 1 \\
& & Wondershare filmora & 1 \\
\hline
\end{tabular}

Pre-service social studies teachers have integrated a total of 37 digital applications into the social studies course content process. Among the applications used, "Thinglink" was the app used the most used in the social studies learning areas. With Thinglink, you can place icons on the images in your presentation and add content such as audio, video, music, pictures, etc. on them. Presentations are usually more interesting and student-engaging activities. For example, by embedding videos on the pictures of touristic areas in certain regions on a tourism map of Turkey, you can satisfy the curiosity of the students by appealing more to the senses. In this respect, it can be said that pre-service teachers focused on practices that facilitate student participation in the process. Other digital applications that pre-service teachers preferred most during the preparation of social studies course content were; Quiziz, Emaze, Learning Apps, Go animate and Mentimeter. Digital applications integrated with social studies courses by only one pre-service teacher were as follows; virtual classroom application: Classdojo, presentation and animation applications: Buncee and Toondoo, Word building applications: Wordle, Bubbl, Word art, Test and puzzle building applications: Plickers, Mind map applications: Mindomo and film-video editing applications: Movie maker, Safeshare and Wondershare filmora respectively. 


\section{What Are the Opinions of Pre-service Social Studies Teachers about the Integration of Pedagogical and Content Knowledge with Digital Technologies?}

Table 4. Opinions of pre-service social studies teachers about their contribution to professional competence

\begin{tabular}{|c|c|c|c|}
\hline \multirow{14}{*}{ 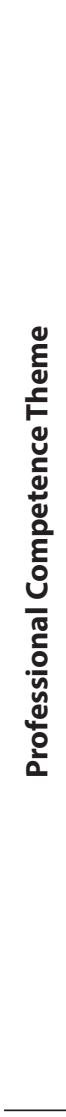 } & Opinions of pre-service teachers & Participants & $\mathbf{f}$ \\
\hline & $\begin{array}{l}\text { Being able to integrate digital technologies with content knowledge } \\
\text { within the framework of pedagogical knowledge }\end{array}$ & $\begin{array}{l}\mathrm{P} 1, \mathrm{P} 2, \mathrm{P} 3, \mathrm{P} 4, \mathrm{P} 5, \mathrm{P} 6, \mathrm{P} 7, \mathrm{P} 8, \mathrm{P} 9, \\
\mathrm{P} 10, \mathrm{P} 13, \mathrm{P} 14, \mathrm{P} 15, \mathrm{P} 18, \mathrm{P} 20, \mathrm{P} 21, \\
\mathrm{P} 23, \mathrm{P} 24, \mathrm{P} 25, \mathrm{P} 26, \mathrm{P} 28, \mathrm{P} 29, \mathrm{P} 30\end{array}$ & 23 \\
\hline & Increased knowledge and skills about digital applications over time & $\begin{array}{l}\mathrm{P} 1, \mathrm{P} 3, \mathrm{P} 5, \mathrm{P} 8, \mathrm{P} 11, \mathrm{P} 12, \mathrm{P} 15, \mathrm{P} 16, \\
\mathrm{P} 17, \mathrm{P} 19, \mathrm{P} 22, \mathrm{P} 23, \mathrm{P} 28\end{array}$ & 13 \\
\hline & Regarding the use of technology, gaining a positive attitude & P1, P7, P23, P25, P26 & 5 \\
\hline & Increasing curiosity about technology & P17, P29, P30 & 3 \\
\hline & Feeling oneself at a level that can help others & P18, P27, P28 & 3 \\
\hline & $\begin{array}{l}\text { Improving self-confidence about using digital applications in social } \\
\text { studies }\end{array}$ & P4, P17 & 2 \\
\hline & Considering oneself to be different from the classical teacher model & P4, P6, & 2 \\
\hline & $\begin{array}{l}\text { Being able to use applications that most people don't know about in } \\
\text { class is very pleasing }\end{array}$ & P12, P17 & 2 \\
\hline & Destruction of prejudice against technology & P15, P29 & 2 \\
\hline & $\begin{array}{l}\text { Considering oneself to be one of the best in the class to integrate } \\
\text { digital applications with social studies }\end{array}$ & P10 & 1 \\
\hline & $\begin{array}{l}\text { Thinking that the process of integration into social studies increases } \\
\text { creativity as well }\end{array}$ & P6 & 1 \\
\hline & $\begin{array}{l}\text { Gaining the ability to use technological tools in a more controlled and } \\
\text { purposeful manner }\end{array}$ & P15 & 1 \\
\hline & $\begin{array}{l}\text { Finding the opportunity to discover new features and aspects of } \\
\text { oneself in the process }\end{array}$ & P25 & 1 \\
\hline
\end{tabular}

Even though I had no knowledge and interest in using the applications in social studies at the beginning of this course, I am now one of the most effective people in using applications in social studies (P10).

There was an improvement in my ability to visualize and integrate knowledge into the course. I used virtual classes such as Edmodo and Classdojo in social studies and gained competence in observing students and class management (P14).

Before I started to use these applications in social studies, I had difficulty even using computers. Now I can easily use these applications in social studies. In the process of integrating these practices, I began to realize my abilities and interests that I had not noticed before (P25). 
Table 5. Opinions of pre-service social studies teachers about their contributions to social studies course

\begin{tabular}{|c|c|c|c|}
\hline \multirow{10}{*}{ 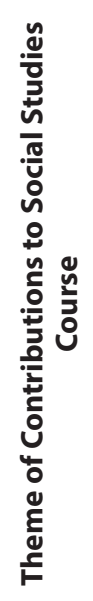 } & Opinions of pre-service teachers & Participants & f \\
\hline & The opinion that digital applications make social studies a more fun course & P1, P3, P8, P25, P26, P20 & 6 \\
\hline & Students in social studies course become more active with digital applications & P3, P11, & 2 \\
\hline & Opportunity to interact with students in virtual classes at any time & P1, P14, & 2 \\
\hline & $\begin{array}{l}\text { The opinion that learnings of social studies become more permanent with the } \\
\text { use of applications }\end{array}$ & P2, P12, & 2 \\
\hline & $\begin{array}{l}\text { The opinion that social studies are prevented from becoming monotonous with } \\
\text { digital applications }\end{array}$ & P1, & 1 \\
\hline & Contribution to the effective teaching of social studies course & P8 & 1 \\
\hline & In the social studies course, digital applications are thought to be useful & P13 & 1 \\
\hline & $\begin{array}{l}\text { The opinion that courses designed in this model support collaborative learning } \\
\text { studies as well }\end{array}$ & P14 & 1 \\
\hline & Saving time with digital applications & P15 & 1 \\
\hline
\end{tabular}

If we want to teach the subjects effectively in the social studies course and have the students participate more, we need to use digital applications. The course becomes even more fun with these applications (P8).

Teaching the course with digital applications will make the learnings of students more permanent. Integrating courses with digital applications instead of just plain talking is important for ensuring that the courses are not boring and that they facilitate student participation (P12).

I have seen that using digital applications in social studies courses saves time. In this way, I can share my presentations and animations with the class in a more practical and fun way (P15).

I realized that there are digital applications that enable my students to work effectively as a team in social studies course. (P14).

Table 6. Opinions on the implementation of the applications in the future during their professional lives

\begin{tabular}{|c|c|c|c|}
\hline \multirow{11}{*}{ 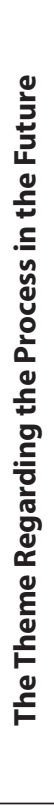 } & Opinions of pre-service teachers & Participants & f \\
\hline & $\begin{array}{l}\text { Regarding the future, the idea of wanting to use the applications more effectively and } \\
\text { productively while teaching }\end{array}$ & $\begin{array}{l}\text { P5, P7, P11, } \\
\text { P13, P21, P24, } \\
\text { P26 }\end{array}$ & 7 \\
\hline & $\begin{array}{l}\text { Regarding the teaching practice, thinking about which digital applications to integrate } \\
\text { with social studies. }\end{array}$ & P4, P12, & 2 \\
\hline & $\begin{array}{l}\text { Regarding the future, belief that social studies course will be more fun to teach with digital } \\
\text { applications }\end{array}$ & P11, P19 & 2 \\
\hline & The opinion that it will be professionally beneficial for oneself & P26, P28 & 2 \\
\hline & $\begin{array}{l}\text { Regarding the future, the idea of becoming a social studies teacher who makes children } \\
\text { enjoy technology }\end{array}$ & P10 & 1 \\
\hline & The opinion that digital applications will motivate students & P1 & 1 \\
\hline & The opinion that with this model, it will be easier to stimulate more senses in the students & P14 & 1 \\
\hline & The opinion that this way students will participate more in class & P19 & 1 \\
\hline & $\begin{array}{l}\text { The idea of closely following technological developments in the future and using them in } \\
\text { class }\end{array}$ & $\mathrm{P} 25$ & 1 \\
\hline & $\begin{array}{l}\text { The belief that the fear of taking tests that students experience will be eased with digital } \\
\text { games }\end{array}$ & P1 & 1 \\
\hline
\end{tabular}

In the future, I will try to use digital applications more and strive to produce richer content (P19).

When we use these applications in class, our lessons become more fun. When we become teachers, I believe that when we use these applications while teaching with our students, they will have more fun while learning (P5).

I think I'll benefit from using digital applications that fit my course subjects when I'm a teacher in the future (P26). 
I can easily draw the attention of my students in the future by blending social studies with digital applications. This will allow my students to see the positive aspects of technology. I also think I'll keep track of the work my students do outside the classroom with virtual classroom applications. I'm planning to help my students get rid of their test anxiety with digital evaluation applications such as digital Kahoot, Quizziz and Triventy and make learning more fun for them (P1).

\section{DISCUSSION AND CONCLUSION}

Teacher competencies are important for improving the quality of teaching in educational environments. Because teachers who are competent and qualified are the ones responsible for teaching the 21 st century knowledge and skills to students in a healthy way. Since one of the competencies that must to be taught to the students as part of curricula is "digital competence", teachers are required to have this skill themselves in the first place and a competent teacher must have the ability to integrate the content knowledge and pedagogical knowledge with digital technologies. The aim of this study is to examine the sample course design studies conducted by pre-service social studies teachers using digital technologies and to describe their opinions about this process. In this context, according to the first question of the research, "How did pre-service social studies teachers design a course in the process of creating a sample course with digital technologies?" it was concluded that each group of pre-service social studies teachers designed a sample social studies course by integrating their content and pedagogical knowledge with digital applications. In relation to this finding of the research, the resulting collaborative work done by pre-service teachers in the process of designing a technology-supported course is consistent with certain other studies ( $\mathrm{Lu}$ et al., 2011; So \& Kim, 2009) as well. Both individual products and common group products were created during the group work. This development prevents the unfair gain which is one of the limitations of the collaborative works. It is also worth pointing out that pre-service teachers applied teaching techniques in social studies courses in the process. In addition to the teaching techniques (e.g. come out come out wherever you are, quick round, hourglass) in the literature, it was observed that pre-service teachers also used instructional activities they created themselves (the stranger next to me, hit the dart answer the question, cast a line get the question) and used their creativity. When the videos of pre-service teachers about the sample social studies course designed with digital technologies were examined, it was concluded that the designs created coincided with the constructivist understanding and student participation as well. The ability of pre-service teachers to design content knowledge and digital applications in such a way to be able to teach them in a classroom environment depends on the soundness of their pedagogical knowledge. Because the use of appropriate teaching methods and techniques for optimizing the knowledge, skills and approach to be gained by the target audience in the process of teaching is related to the pedagogical knowledge that increases the quality of teaching activities (Usak, 2005; Park \& Oliver, 2008; Moore, 2000). In the research "What is the distribution of the content prepared by the pre-service social studies teachers in the process of designing a sample course with digital technologies in terms of grade level, learning area, digital applications and techniques?" was another point of question.

In the findings related to the second question of the research the learning area the participants prepared the most content for during the process of integrating their technological pedagogical content knowledge in the social studies course was seen to be the "Culture and Heritage" (7) learning area. In this area of learning, content was prepared for 5 th, 6 th, and 7 th Grade levels. When the content of culture and heritage learning area is examined, it is seen that it mostly includes historical and cultural issues related to past experiences. Pre-service teachers may have preferred to use this learning field more because they thought about how they could make the lessons more concrete when dealing with historical and cultural issues when they became teachers. Similarly, in the "Global Connections" learning area, technological, pedagogical and content knowledge studies have been carried out extensively for the 5th, 6th, 7th Grades. Again, as the learning area of global connections can be a bit more difficult to teach by simplifying the subjects of international political, economic and cultural relations for the students, teachers may have chosen this field by thinking that this problem can be overcome with digital technologies.

Another interesting finding was the variability in the preferences of pre-service teachers regarding instructional techniques. This finding shows that social studies teachers produce different contents within the scope of 
their creativity. In addition, the creativity of the pre-service teachers also developed during this process as evidenced by the activities such as knock over and win, collect points, playing tag, burst the bubble see the answer, take a hint, cast a line get the question, that they created themselves. Findings related to "Digital technologies extensively used by pre-service social studies teachers in designing sample courses with digital technologies" show that pre-service social studies teachers tried to integrate 37 digital applications into social studies course content process. Among the applications, "Thinglink" (f-8) was the most widely used application in social studies learning areas. Via Thinglink, you can place icons on the images in your presentation and add content such as audio, video, music, pictures, etc. on them. Presentations are usually more interesting and student-engaging activities. In this respect, it can be said that pre-service teachers focused on practices that facilitate student participation in the process. The result is in parallel with the idea that technology enriches the educational environment (Melia et al., 2012; Mishra and Koehler, 2006).

Other digital applications that pre-service teachers preferred most during the preparation of social studies course content were; Quiziz, Emaze, Learning Apps, Go animate and Mentimeter. Digital applications integrated with social studies courses by only one pre-service teacher were as follows; virtual classroom application: Classdojo, presentation and animation applications: Buncee and Toondoo, Word building applications: Wordle, Bubbl, Word art, Test and puzzle building applications: Plickers, Mind map applications: Mindomo and film-video editing applications: Movie maker, Safeshare and Wondershare Filmora respectively. The finding related to the question of "What are the opinions of pre-service social studies teachers about the process of designing a sample course with digital technologies?" was also acquired in the research. As a result of the data obtained from the opinions of pre-service teachers on this subject three themes of "contribution to their professional competence," "contribution to social studies course," "implementation in the future professional life" and opinions within the context of these themes were acquired. From among the opinions acquired; being able to integrate digital technologies with content knowledge within the framework of pedagogical knowledge over time, considering oneself to be different from the classical teacher model, thinking that the process of integration into social studies increases creativity as well, the opinion that digital applications make social studies a more fun course, the opinion that students in social studies course become more active with digital applications, the benefits of the opportunity to interact with students in virtual classes at any time, the opinion that courses designed in this model support collaborative learning studies as well, the idea of wanting to use the applications more effectively and productively while teaching were the most striking ones.

When all these findings are taken into consideration, it can be said that they coincide with the opinion that technological infrastructure of the universities should be developed and improved in terms of qualified and competent academic staff and that the training of pre-service teachers to be organized accordingly (Kurt, 2013). Considering the triad of technological pedagogical and content knowledge usage achieved in this study, it is also concluded that the advice of Koehler and Mishra (2005) regarding those responsible for training teachers to train them to be able to use technological tools correctly and properly, is also followed. Therefore, the study's finding that technology integration can be compensated by pre-service training, strengthens Hur et al. (2010)'s views.

\section{Recommendations}

Based on the literature and the finding of this study, it is recommended that pre-service training activities should be focused on deep-rooted solutions in the use of technology in integration with courses. In this regard, projects involving face to face training for all academics could be implemented and vocational courses in the Department of Education can be taught more practically. This study was conducted only with social studies teachers. However, similar course designs can be carried out in different branches. In order to observe the effects of the education given to pre-service teachers in real classroom environments, longitudinal researches including the process of teaching practice can be conducted. 


\section{BIODATA and CONTACT ADDRESSES of AUTHOR}

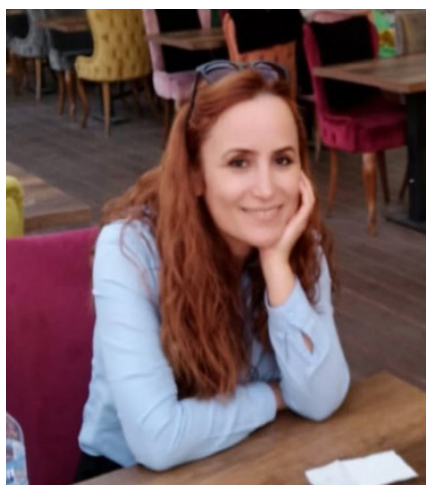

Dr. Turkan CELIK is an assistant Professor Doctor, at Kilis 7 Aralik University, Faculty of Education, Depertmant of Turkish and Social Sciences Education, Division of Social Studies Education. Dr. CELIK gained her PhD from Pamukkale University Primary Education Phd in 2016. Her Phd thesis about An Investigation on The Benefits and Risks of Social Media from Stakeholders 'Perspective. She has been working at Kilis 7 Aralik University since 2018. Her research interests include social studies education, teacher education, social media literacy, digital literacy, technology integration social studies, Web 2.0 training. She has journal articles published in national and international indexes, book chapters, and papers submitted to international meetings

\section{Turkan CELIK}

Kilis 7 Aralik University, Faculty of Education Department of Social Studies Education

Address: Kilis 7 Aralik University, Faculty of Education, 79000, Kilis, Turkey

Phone: + 9034881426 66-1722

E-mail: turkancelik@kilis.edu.tr

\section{REFERENCES}

Abbitt, J., \& Klett, M. (2007). Hizmet oncesi egitimciler arasinda teknoloji entegrasyonuna yonelik tutum ve oz yeterlik inanclari uzerindeki etkilerin belirlenmesi. Egitimde Teknoloji Entegrasyonu Elektronik Dergisi, 6, 28-42

Altunisik, Remzi, Coskun, Bayraktaroglu \& Yildirim. (2007). Sosyal Bilimlerde Arastirma Yontemleri: Spss Uygulamali. 4. Baski. Istanbul: Avci Ofset.

Angeli C. \& Valanides, N., (2009). Epistemological and methodological issues for the conceptualization, development, and assessment of ICT-TPCK: Advances in technological pedagogical content knowledge (TPCK). Computers \& Education, 52, 154-168.

Kurt, A. A. (2013). Teknopedagojik egitim modeli. I. Kabakci Yurdakul (Editor). Egitimde teknoloji Entegrasyonuna Kavramsal ve Kuramsal Bakis icinde (s. 3-37). Ankara: Ani Yayincilik.

Baki, A. (2002). Bilgisayar destekli matematik. Istanbul: Ceren Yayin Dagitim.

Benzer, A. (2017). Dijital Cagda Ogretim Teknolojileri ile Turkce Egitimi, Ankara: Yeni Anadolu Yayincilik.

Bozkurt, A. (2019). Vizyon 2023: Turkiye'de acik ve uzaktan ogrenme alaninda somut ve soyut teknolojiler baglaminda egilimler. Acikogretim Uygulamalari ve Arastirmalari Dergisi, 5(4), 43-64.

Brown, A., \& Campione, J. (1996). Psychological theory and the design of innovative learning environments: On procedures, principles, and systems. L. Schauble ve R. Glaser (Eds.), Innovations in learning: New environments for education icinde (289-325). Mahwah, NJ: Lawrence Erlbaum Associates.

Brown, A. L. (1992). Design experiments: Theoretical and methodological challenges in creating complex interventions in classroom settings. Journal of the Learning Sciences, 2(2), 141-178.

Brown, D., \& Warschauer, M. (2006). From the university to the elementary classrooms: Students' experiences in learning to integrate technology in instruction. Journal of Technology and Teacher Education, 14(3), 599-621.

Buyukozturk, S., Kilic Cakmak E., Akgun, O. E., Karadeniz, S., \& Demirel, F. (2008). Bilimsel arastirma yontemleri. Ankara: PegemA Yayincilik.

Chou, C. M. (2011). Student teachers socialization development by teaching blog: Reflections and socialization strategies. TOJET: The Turkish Online Journal of Educational Technology, 10(2), 190-201. 
Cobb, P., Confrey, J., diSessa, A., Lehrer, R. \& Schauble, L. (2003). Design experiments in educational research. Educational Researcher, 32(1), 9-13.

Collins, A. (1992). Towards a design science of education. E. Scanlon ve T. O'Shea (Eds.), New directions in educational technology icinde (15-22). Berlin: Springer.

Collins, A., Joseph, D., \& Bielaczyc, K. (2004). Design research: Theoretical and methodological issues. Journal of the Learning Sciences, 13(1), 15-42.

Collis, B., \& Moonen, J. (2008). Web 2.0 Tools and Processes in Higher Education: Quality Perspectives. Educational Media International, 45 (2), 93-106.

Design-Based Research Collective (2003). Design based research: An emerging paradigm for educational inquiry. Educational Researcher, 32(1), 5-8.

Doering, A., Hughes, J., \& Huffman, D. (2003). Preservice teachers: Are we thinking with technology? Journal of Computing in Teacher Education, 35(3), 342-361.

Ertmer, P. A. (2005). Teacher pedagogical beliefs: The final frontier in our quest for technology integration? Educational technology research and development, 53(4), 25-39.

Esgi, N., \& Kocadag Unver, T. (2018). Bilisim Teknolojileri, Ogretim Teknolojileri, Materyal Gelistirme Icin Web 2. O Araclari, Ankara: Nobel Akademi Yayincilik.

Glesne, C. (2013). Nitel arastirmaya giris. Ani Yayincilik.

Gomleksiz, M. N., \& Fidan, E. K. (2011). Pedagojik Formasyon Programi Ogrencilerinin Web Pedagojik Icerik Bilgisine Iliskin Oz-Yeterlik Algi Duzeyleri. Turkish Studies International Periodical For The Languages, Literature and History of Turkish or Turkic, 6(4), 593-620.

Graham, R. C., Burgoyne, N., Cantrell, P., Smith, L., St Clair, L., \& Harris, R. (2009). Measuring the TPACK confidence of inservice science teachers. TechTrends, 53(5), 70-79.

Gunduz, S. (2007). Ogretmen Egitiminde Bilgi ve Iletisim Teknolojileri Planlama Rehberi, H. Ferhan Odabasi (Ceviri Ed.), Bilgive Iletisim Teknolojileri ve Ogretmen Egitimi: Kuresel Baglam ve Yapi (s. 5-22), Ankara: Nobel Akademi Yayincilik.

Gununc, S. (2017). Egitimde Teknoloji Entegrasyonunun Kuramsal Temelleri, Ankara: Ani Yayincilik.

Hew, K. F., \& Brush, T. (2007). Integrating technology into K-12 teaching and learning: Current knowledge gaps and recommendations for future research. Educational Technology Research and Development, 55(3), 223-252.

Hur, J. W., Cullen, T., \& Brush, T. (2010). Teaching for application: A model for assisting preservice teachers with technology integration. Journal of Technology and Teacher Education, 18(1), 161-182.

ISTE (Uluslararasi Egitim Teknolojileri Toplulugu -International Society for Technology in Education), 2019. Standart for educators, https://www.iste.org/standards/for-educators, Erisim tarihi: 12.02.2019.

ISTE (Uluslararasi Egitim Teknolojileri Toplulugu -International Society for Technology in Education), (2019). Standart for Students, http://www.iste.org/standards/for-students Erisim tarihi: 12.02.2019.

Kariuki, M., \& Duran, M. (2004). Using anchored instruction to teacher preservice teachers to integrate technology in the curriculum. Journal of Technology and Teacher Education, 12(3), 431-445.

Kazanci, A., \& Donmez, F. I. (2013). OKUL 2.0 Egitimde Sosyal Medya ve Mobil Uygulamalar, Ankara: Ani Yayincilik.

Kelly, A.E. (2003). The role of design in educational research. Educational Researcher, 32(1).

Koehler, M.J., \& Mishra, P. (2005). What happens when teachers design educational technology? The development of technological pedagogical content knowledge. Journal of Educational Computing Research, 32(2), 131-152. 
Lee, C. B., Chai, C. S., Teo, T., \& Chen, D. (2008). Preparing Pre-Service Teachers' for the Integration of ICT Based Student-Centered Learning (SCL) Curriculum. Journal of Education, 13, 15-28.

Levin, J.R., \& O'Donnell, A.M. (1999). What to do about educational research's credibility gaps? Issues in Education, 5(2), 177-229.

Lu, L., Johnson, L., Tolley, L.M., Gilliard-Cook, T., \& Lei, J., (2011). Learning by design: TPACK in action. Technology integration preparation for preservice teachers. In C. D. Maddux et al. (Eds.), Research highlights in technology and teacher education, (pp. 47-54). Chesapeake: The Society for Information Technology \& Teacher Education.

Mayring, P. (2011). Nitel sosyal arastirmaya giris. Bilgesu Yayincilik

Mazman, S. G., \& Kocak U. Y. (2011). Bilgi ve iletisim teknolojilerinin ogrenme-ogretme sureclerine entegrasyonu: Modeller ve gostergeler. Egitim Teknolojisi Kuram ve Uygulama, 1(1), 62-79.

Melia, J. M. J., Gonzalez-Such, J., \& Garcia-Bellido, M. R. (2012). Evaluative research and information and communication technology (ICT). Revista Espanola De Pedagogia, 70 (251), 93-110.

Meric, G. (2014). Fen ve teknoloji ogretmen adaylarinin teknolojik pedagojik alan bilgisi konusunda oz guven seviyelerinin belirlenmesi. Egitimde Kuram ve Uygulama, 10(2), 352-367.

Merriam, S. B. (2013). Nitel arastirma desen ve uygulama icin bir rehber. Ankara: Nobel Yayin Dagitim.

Mishra, P. \& Koehler, M.J. (2006). Technological pedagogical content knowledge: A new framework for teacher knowledge. Teachers College Record, 108 (6), 1017-1054.

Moore, K. D. (2000). Ogretim becerileri. (Ed. E. Altintas), (Cev. N. Kaya). Ankara: Nobel Yayinevi.

Goksun, D. O., \& Kurt, A. A. (2018). Ogretim teknolojilerinin temelleri, Kurt, A. A., (Ed.), 21. Yuzyil Ogrenci ve Ogretmen Becerileri (s. 95-114). Ankara: Nobel Akademi Yayincilik.

Onal, N. (2018). Etkinlik Ornekleriyle Zenginlestirilmis Egitimde Teknoloji Uygulamalari, Onal, N. (Ed.), Ogretimde Kullanilabilecek Teknoloji Destekli Uygulamalar, (s.2-13). Ankara: Pegem Akademi.

Pamuk, S., Ulken, A. \& Dilek, N. S. (2012). Ogretmen adaylarinin ogretimde teknoloji kullanim yeterliliklerinin teknolojik pedagojik icerik bilgisi kuramsal perspektifinden incelenmesi. Mustafa Kemal Universitesi Sosyal Bilimler Enstitusu Dergisi, 9(17), 415-438.

Park, S. \& Oliver, J. S. (2008). Revisiting the Conceptualisation of Pedagogical Content Knowledge (PCK): PCK as a Conceptual Tool to Understand Teachers as Professionals. Research in Science Education, 38(3), 261-284.

Partnership for 21st Century Learning (2015). P21 Framework Definitions. Erisim adresi: https://files.eric. ed.gov/fulltext/ED519462.pdf.

Pope, M., Hare, P., \& Howard, E. (2002). Technology integration: Closing the gap between what preservice teachers are taught to do and what they can do. Journal of Technology and Teacher Education, 10(2), 191-203.

Russell, M., Bebell, D., O’Dwyer, L., \& O’Connor, K. (2003). Examining teacher technology use: Implications for preservice and inservice teacher preparation. Journal of Teacher Education, 54(4), 297-310.

Shulman, L. S. (1986). Those who understand: Knowledge Growth in teaching. Educational Researcher, 15(2), 4-14

So, H.J., \& Kim, B., (2009) Learning about problem based learning: Student teachers integrating technology, pedagogy and content knowledge. Australasian Journal of Educational Technology, 25(1), 101-116.

Sahin, Y. L. (2013). Teknopedagojik Egitime Dayali Ogretim Teknolojileri ve Materyal Tasarimi, Kabakci Yurdakul, I. (Ed.), Teknopedagojik Egitimde Web 2. 0 araclari (s. 163-192), Ankara: Ani Yayincilik.

Tatli, Z. (2017). Kavram Ogretiminde Web 2. 0, Tatli, Z. (Ed.), Pixton, (s. 262-273). Ankara: Pegem Akademi. 
Trilling, B., \& Fadel, C. (2009). 21st century skills: Learning for life in our times Francisco: Jossey-Bass.

Turkan Hoca Dijital Materyal Egitimi. (2019, Haziran 7). Turkan Celik sosyal bilgiler 3. sinif ozel ogretim yontemleri [Video]. YouTube. https://www.youtube.com/playlist?list=PLHl-bVQNArEcf9_3wzBa6_MytokteLdA

URL-1: MEB (Milli Egitim Bakanligi) Sosyal bilgiler ogretim programi, (2018) 23. 01. 2017 tarihinde http://mufredat.meb.gov.tr/Dosyalar/201812103847686SOSYAL\%20 B\%C4\%B0LG\%C4\%B0LER\%20\%C3\%96\%C4\%9ERET\%C4\%B0M\%20PROGRAMI\%20. pdf. adresinden erisilmistir.

Usak, M. (2005). Fen bilgisi ogretmen adaylarinin cicekli bitkiler konusundaki pedagojik alan bilgileri. Yayimlanmamis doktora tezi. Gazi Universitesi, Ankara.

Yildirim, A. ve Simsek, H. (2013). Sosyal bilimlerde nitel arastirma yontemleri, Ankara: Seckin Yayincilik.

URL-2: K1 TPAB Videosu, Erisim adresi (2019, Aralik 7): https://www.youtube.com/ watch?v=1iSMxiPdgVA\&list=PLHl-bVQN-ArEcf9_3wzBa6_MytokteLdA\&index=14,https:// www.youtube.com/watch?v=_k-AIU3SoIQ\&list=PLHl-bVQN-ArEcf9_3wzBa6_ MytokteLdA\&index $=3 \& \mathrm{t}=112 \mathrm{~s}$

URL-3: K5 TPAB Videosu, Erisim adresi (2019, Aralik 7): https://www.youtube.com/watch?v=cRWgOWQn60\&list=PLHI-bVQN-ArEcf9_3wzBa6_MytokteLdA\&index=3, https:// www.youtube.com/watch?v=8MLINK5wyR0 \&list=PLHl-bVQN-ArEcf9_3wzBa6_ MytokteLdA\&index $=4$

URL-4: K8 TPAB Videosu, Erisim adresi (2019, Aralik 7): https://www.youtube.com/watch?v=B7 E28ZC0fU\&list=PLHI-bVQN-ArEcf9_3wzBa6_MytokteLdA\&index=8\&t=0s, https:// www.youtube.com/watch?v=fUYxqPPGttY\&list=PLHl-bVQN-ArEcf9_3wzBa6_ MytokteLdA\&index $=8$

URL-5: K9 TPAB Videosu, Erisim adresi (2019, Aralik 7): https://www.youtube.com/

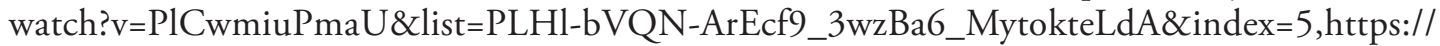
www.youtube.com/watch?v=Xmm5LZCyqEo\&list=PLHl-bVQN-ArEcf9_3wzBa6_ MytokteLdA\&index $=6$

URL-6: K10 TPAB Videosu, Erisim adresi (2019, Aralik 7): https://www.youtube.com/ watch?v=BTOUAesszb0\&list=PLHl-bVQN-ArEcf9_3wzBa6_MytokteLdA\&index=1,2) https://www.youtube.com/watch?v=_k-AIU3SoIQ\&list=PLHl-bVQN-ArEcf9_3wzBa6_ MytokteLdA\&index $=2$

URL-7: K11 TPAB Videosu, Erisim adresi (2019, Aralik 7): https://www.youtube.com/ watch?v=9CK1L8xWUIY\&list=PLHl-bVQN-ArEcf9_3wzBa6_MytokteLdA\&index=31, https://www.youtube.com/watch?v=eekwlWxQmX8\&list=PLHl-bVQN-ArEcf9_3wzBa6_ MytokteLdA\&index=32

URL-8: K17 TPAB Videosu, Erisim adresi (2019, Aralik 7): https://www.youtube.com/ watch?v=TrBcbKQypE0\&list=PLHl-bVQN-ArEcf9_3wzBa6_MytokteLdA\&index=35,https:// www.youtube.com/watch?v=4ZwMYLcjvtA\&list=PLHl-bVQN-ArEcf9_3wzBa6_ MytokteLdA\&index $=36$ 